\title{
Ectomycorrhizal and endophytic fungi associated with Alnus glutinosa growing in a saline area of central Poland
}

\author{
Dominika Thiem $^{1}$ - Agnieszka Piernik ${ }^{2}$ - Katarzyna Hrynkiewicz ${ }^{1}$
}

Received: 20 January 2017 / Accepted: 12 September 2017 /Published online: 22 September 2017

(C) The Author(s) 2017. This article is an open access publication

\begin{abstract}
Alnus glutinosa (black alder) is a mycorrhizal pioneer tree species with tolerance to high concentrations of salt in the soil and can therefore be considered to be an important tree for the regeneration of forests areas devastated by excessive salt. However, there is still a lack of information about the ectomycorrhizal fungi (EMF) associated with mature individuals of A. glutinosa growing in natural saline conditions. The main objective of this study was to test the effect of soil salinity and other physicochemical parameters on root tips colonized by EMF, as well as on the species richness and diversity of an EMF community associated with A. glutinosa growing in natural conditions. We identified a significant effect of soil salinity (expressed as electrical conductivity: $\mathrm{EC}_{\mathrm{e}}$ and $\mathrm{EC}_{1: 5}$ ) on fungal taxa but not on the total level of EM fungal colonization on roots. Increasing soil salinity promoted darkcoloured EMF belonging to the order Thelephorales (Tomentella sp. and Thelephora sp.). These fungi are also commonly found in soils polluted with heavy-metal. The ability of these fungi to grow in contaminated soil may be due to the presence of melanine, a natural dark pigment and common wall component of the Thelephoraceae that is known to act as
\end{abstract}

Electronic supplementary material The online version of this article (https://doi.org/10.1007/s13199-017-0512-5) contains supplementary material, which is available to authorized users.

Katarzyna Hrynkiewicz

hrynk@umk.pl

1 Department of Microbiology, Faculty of Biology and Environmental Protection, Nicolaus Copernicus University, Lwowska 1, PL-87-100 Torun, Poland

2 Chair of Geobotany and Landscape Planning, Faculty of Biology and Environmental Protection, Nicolaus Copernicus University, Lwowska 1, PL-87-100 Torun, Poland a protective interface between fungal metabolism and biotic and abiotic environmental stressors. Moreover, increased colonization of fungi belonging to the class of Leotiomycetes and Sordiomycetes, known as endophytic fungal species, was observed at the test sites, that contained a larger content of total phosphorus. This observation confirms the ability of commonly known endophytic fungi to form ectomycorrhizal structures on the roots of A. glutinosa under saline stress conditions.

Keywords ectomycorrhizal fungi (EMF) · Alnus glutinosa L. · black alder $\cdot$ salinity $\cdot$ saline stress

\section{Introduction}

The genus Alnus Mill. (alder) belongs to the family Betulaceae and comprises approximately 35 species that are widely distributed in humid locations of boreal, temperate and tropical climate zones (Põlme et al. 2013). Black alder (Alnus glutinosa L.) tolerates poor soils and is an important tree with many medicinal values (Sati et al. 2011; Sakalli 2013). Black alder is native to a number of countries in northern Africa, temperate Asia and across all of Europe. In most European countries, black alder represents approximately $1-5 \%$ of forest areas. Although it is relatively rare in highly productive stands of forests, alder has a good potential to produce timber, and at optimal conditions, can grow as quickly as ash, maple or cherry (Claessens et al. 2010). Black alder is a pioneer tree species and is important in the process of forest regeneration due to its ability to fix nitrogen that generates a specific soil condition and improves its quality. This tree species can increase the development of other plant species and consequently facilitate plant succession (Obidziński 2004). Moreover, A. glutinosa tolerates diverse environmental conditions, is 
effective at restoring fertility in mountains, and inhibits erosive processes (Nouhra et al. 2014). According to the indicator values determined by Ellenberg et al. (2001), black alder can tolerate small amounts of chlorides in the soil (indicator value 2: $0.05-0.3 \% \mathrm{Cl}^{-}$).

Microorganisms associated with the roots of many trees, such as symbionts, endophytic fungi, and bacteria, can synthesize plant growth regulators that facilitate the development and functioning of plants in unfavourable soil conditions and buffer the effects of soil toxic compounds and soil-borne pathogens (Selosse et al. 2004; Tedersoo et al. 2009a; Hrynkiewicz and Baum 2012). The group of root-associated microorganisms contains mycorrhizal and endophytic fungi, mycorrhization helper bacteria (MHB), nitrogen-fixing actinobacteria and rhizobia. Their function and ecology differ substantially depending on host species and soil parameters (Tedersoo et al. 2009b; Hrynkiewicz and Baum 2012). Black alder is known to form symbiotic relationships with nitrogenfixing bacteria such as Frankia alni (Claessens et al. 2010), but knowledge of its mycorrhizal associations under environmental stress conditions, especially in highly saline areas, is lacking. One exception comes from the research of Põlme et al. (2013). It is known that Alnus sp. is among the few dual mycorrhizal tree species that can be colonized by ectomycorrhizal (EM) and arbuscular (AM) fungi at the same time (Pritsch et al. 1997; P ttsepp et al. 2004). However, AM fungi are more important in the early stages of plant growth, while EMF dominate in mature plants (P ttsepp et al. 2004). Thus far, approximately 80 species of EMF have been documented as mycorrhizal symbionts of Alnus sp. (Roy et al. 2013). The genus Alnus is very specialized in terms of its ectomycorrhizal fungal associations and displays little infrageneric mycorrhizal specificity, which could be due to the effects of phenolics and possible mechanisms to determine ectomycorrhizal specificity (Molina et al. 1992; Kennedy et al. 2014). In forest ecosystems, ectomycorrhizal fungi have a crucial role in improving nutrient and water uptake in hosttrees, protecting plants against biotic stress such as root pathogens and abiotic stress such as heavy-metal contamination, drought, and salinity (Parádi and Baar 2006; Hrynkiewicz and Baum 2012). However, the beneficial effects of EMF are species-specific and depend on environmental conditions, as each EM fungal species has different physiological and ecological traits (Ishida et al. 2009).

Salinity, which is increasing rapidly as a result of anthropogenic factors, is one of the most important abiotic stressors and can significantly limit tree growth by affecting the majority of physiological functions (Ishida et al. 2009; Chen et al. 2014). Ectomycorrhizal associations can increase plant tolerance to salinity by excluding salts and improving nutrient conditions. Ectomycorrhizal fungi can increase the levels of $\mathrm{N}, \mathrm{P}, \mathrm{Ca}^{2+}$ and $\mathrm{K}^{+}$in plant cells (Chen et al. 2014). It appears that higher $\mathrm{K}^{+}$uptake by mycorrhizal plants under salt stress conditions can help maintain a high $\mathrm{K}^{+} / \mathrm{Na}^{+}$ratio, thus preventing the disruption of various enzymatic processes and the inhibition of protein synthesis (Chandrasekaran et al. 2014). Moreover, mycorrhizal fungi reduce osmotic stress on the soil by increasing both the efficiency of water uptake (Cabot et al. 2014) and the synthesis of antioxidants, that in turn protect host plants against adverse ROS (reactive oxygen species) produced in response to salt stress (Cabot et al. 2014; Chandrasekaran et al. 2014). However, a high level of soil salinity may also have a negative impact on such EM associations as colonization capacity and the growth of fungal hyphae in the soil (Hameed et al. 2014; Hrynkiewicz et al. 2015). It has already been confirmed that the level of EM fungal colonization generally decreases with increasing substrate salinity in vitro and in situ (Aggarwal et al. 2012). The level of EM colonization in Alnus roots has been considered in only a few reports to date (Helm et al. 1996; Becerra et al. 2005; Pritsch et al. 2010) that investigated the intensity of EMF colonization under salt stress condition. The salt tolerance of EMF can differ among species (Dixon et al. 1993) and among isolates within a species of fungus (Chen et al. 2001). Moreover, some AMF can tolerate up to $2.5 \mathrm{M} \mathrm{NaCl}$ (Kernaghan et al. 2002). The taxonomic diversity of alder EMF fungi is relatively well known (e.g. Tedersoo et al. 2009a; Roy et al. 2013; Põlme et al. 2013). However, to the best of our knowledge, this is the first study focuses on alder EMF fungi under salt stress conditions.

Alders have been used extensively on industrial scales in forestry, nursery planting, and the re-vegetation of contaminated land (Roy et al. 2007; Diagne et al. 2013) as well as in the context of saline areas. Lefrancois et al. (2010) studied the effects of growing alders on the soil quality of Canadian oil sand tailings and demonstrated that alder plantations substantially increased the soil quality after two growing seasons by augmenting the organic matter content and decreasing the soil $\mathrm{pH}$ that led to a decrease in salinity. Their natural capabilities, combined with an analysis of EM fungal structure, may prove useful to rehabilitate of devastated saline ecosystems. Broader knowledge of alder ectomycorrhizae could significantly improve the technologies used during the reforestation of devastated habitats.

Our research examines the EMF associated with black alder growing in a saline area of central Poland. The aim of our research was to test the effect of soil salinity and other physicochemical parameters on the proportion of the root tip colonized by EMF and on the species richness and diversity of the EMF community associated with A. glutinosa roots, in natural conditions. We propose that: (i) increasing salt concentrations can decrease the level of EM colonization as the plant-fungus system responds to stress conditions, and (ii) salinity can preferentially promote fungal taxa with higher adaptation to this unfavourable soil parameter. 


\section{Materials and methods}

\subsection{Site description and sampling}

The study was carried out in Słonawy, in central Poland. The main cause of the salinity in this area was the evaporation of the long-term shallow and warm sea that existed in this area during the Permian era. In the subsequent period, as a result of tectonic movements, salt and gypsum were laid down on the surface and formed salt pillars. In Słonawy, natural sources of salt are found at a depth of $1636 \mathrm{~m}$ (Wilkoń-Michalska 1963). A saltwater spring has been known to exist in Słonawy since the Middle Ages (Szulczewski 1954). Land reclamation of this area was performed after the World War II and resulted in a considerable decrease in the surface area of salt meadows. Currently, the salt marsh covers approximately one ha. The area under analysis is included in State Forests. A. glutinosa was planted at this area in 1995 (State Forests, personal communication). Samples were collected from five selected plots (I, II, III, IV and V) in five replicates ( 25 in total). Root and soil samples $(20 \times 20 \mathrm{~cm}, 20 \mathrm{~cm}$ deep $)$ were collected in autumn 2013.

\subsection{Soil description and analysis}

Three soil samples were collected from each plot (I-V), air dried for $48 \mathrm{~h}$ and analysed in triplicate (nine replicates in total per test site). The content of organic matter (OM) and organic carbon (C) were determined according to the methods of Bednarek (2005). The methods described by van Reeuwijk (2002) were applied to determine: the total nitrogen $\left(\mathrm{N}_{t}\right)$, phosphorus $(\mathrm{P})$ and phosphorus soluble in $1 \%$ citric acid solution $\left(\mathrm{P}_{2} \mathrm{O}_{5} \mathrm{ca}\right)$, reaction in saturated extract $\left(\mathrm{pH}_{\mathrm{e}}\right)$ and in 1:5 soil-to-water extract $\left(\mathrm{pH}_{1: 5}\right)$, salinity expressed as electrical conductivity $\left(\mathrm{EC}_{\mathrm{e}}\right)$ in a saturated extract and in 1:5 soil-towater extract $\left(\mathrm{EC}_{1: 5}\right)$, and as the concentration of chloride in a saturated extract $\left(\mathrm{Cl}_{\mathrm{e}}{ }^{-}\right)$, moisture (M), and saturation percentage (SP). Additionally, the M:SP ratio was calculated to assess the level of soil saturation.

\subsection{EM colonization of fine root tips}

The analysis was performed as described by Hrynkiewicz et al. (2009, 2015). The number of living non-colonized root tips versus the visually colonized EM root tips was counted using the formula: root tips $\times 100 \%$ / total number of root tips (Agerer 1991). The morpho-anatomical EM fungal types were distinguished by the macroscopic characteristic of the fungal mantle, its colour and surface appearance, the presence of emanating hyphae and hyphal strands, and microscopic features such as the mantle type and hyphal connections (Agerer 1987-2002). Two to five root tips per morphotype found in each analysed sample were frozen separately in Eppendorf tubes and stored at $20{ }^{\circ} \mathrm{C}$ for molecular analysis.

\subsection{Molecular and phylogenetic analysis of EM fungi}

DNA was extracted from the EM root tips using the Plant \& Fungi Purification Kit (EurX, Poland) according to the manufacturer's protocol. The fungal taxa were identified based on the internal transcribed spacer (ITS) region of the rDNA. The PCR analysis and the DNA sequencing were conducted as described by Hrynkiewicz et al. (2009, 2015). The identification process required a minimum of $98 \%$ similarity to the sequence investigated with reference sequences deposited in GenBank and/or the UNITE nucleotide database. Contigs of ITS sequences were aligned using Clustal W (Thompson et al. 1997). Phylogenetic relationships were investigated using PAUP, version 4.0b10 (Swofford 2002): Neighbour-joining analyses were performed with Kimura 2-parameter genetic distances (Kimura 1980) combined with bootstrap analyses (Felsenstein 1985) from 1000 replicates.

\subsection{Statistical analyses}

The tested plots were ordered by increasing level of salinity $\left(\mathrm{EC}_{\mathrm{e}}\right)$ obtained by physicochemical analysis of their soil. Differences in the abundance of EMF and non-mycorrhizal root tips (NM) for all of the research plots (I-V) were investigated using the nonparametric Kruskal - Wallis test and the Dunn test for post hoc comparisons (Statistica ver. 7, StatSoft 1995). Differences between the soil parameters at the five plots (I-V) were tested using the same method. Redundancy Analysis (RDA) was performed for the EMF colonization of A. glutinosa and soil properties, and the percentages of fungal symbionts in molecular analysis and soil properties were distinguished in molecular analysis and soil properties. The relative importance and statistical significance of each environmental factor in the ordination model was assessed by a forward selection procedure and the Monte Carlo permutation test. The ordination method was applied using the Canoco 4.5 package (ter Braak and Šmilauer 2002). For each plot $(\mathrm{I}-\mathrm{V})$ : the number of species $(\mathrm{S})$, and the Shannon - Wiener index of diversity $\left(\mathrm{H}^{\prime}\right)$ were calculated according to the formula:

$H^{\prime}=-\sum_{i=l}^{S} p_{i} \ln p_{i}$,

where $p_{i}$ is the proportion $\left(\mathrm{n} \mathrm{N}^{-1}\right)$ of individuals of one particular species found (n) divided by the total number of individuals found $(\mathrm{N})$, and $\mathrm{S}$ is the number of species (Shannon 1948). In our calculation, one ectomycorrhizal root tip was considered to be an individual. Differences between $\mathrm{S}$ and $\mathrm{H}$ ' at the five plots investigated (I-V) were tested by ANOVA and Tukey's tests for post hoc comparisons (Statistica ver. 7, 
StatSoft 1995). S and $\mathrm{H}^{\prime}$ were analysed in relation to the level of salinity $\left(\mathrm{EC}_{\mathrm{e}}, \mathrm{EC}_{\mathrm{e} 1: 5}\right)$ and the total phosphorus level (correlation matrix) since both parameters significantly affected the fungal distribution observed in the RDA analysis (Statistica ver. 7, StatSoft 1995). All statistic tests utilized an alpha error at the 0.05 level.

\section{Results}

\subsection{Physicochemical soil analysis}

The level of electrical conductivity in the saturated extract $\left(\mathrm{EC}_{\mathrm{e}}\right)$ differed at the five test sites studied and ranged between 2.54 and $6.85\left(\mathrm{dS} \cdot \mathrm{m}^{-1}\right)$ (Table 1$)$. Classification of soil salinity level at the five test sites can be described according to Richards (1954) and Jackson (1958) as slightly saline at sites I and II (2-4 $\mathrm{dS} \cdot \mathrm{m}^{-1}$ of saturated extract) and moderately saline at sites III $-\mathrm{V}\left(4-8 \mathrm{dS} \cdot \mathrm{m}^{-1}\right)$. The analysis of electrical conductivity in the 1:5 extract $\left(\mathrm{EC}_{1: 5}\right)$ showed significant differences between test sites I and III (403 and $760 \mathrm{dS} \cdot \mathrm{m}^{-1}$, respectively) and, in the case of chloride content $\left(\mathrm{Cl}_{\mathrm{e}}\right)$, between the test sites I and IV (717 and $1867 \mathrm{mg} \cdot \mathrm{dm}^{-1}$, respectively). Significantly different values of organic matter (OM), organic carbon $(C)$ and total nitrogen $\left(\mathrm{N}_{t}\right)$ were observed for plot I (the highest) and plot $\mathrm{V}$ (the lowest). Additionally, plot IV had the lowest $\mathrm{pH}$ value (4.8) and $\mathrm{P}$ content (31.4 $\left.\mathrm{mg} \cdot \mathrm{kg}^{-1}\right)$ The moisture content $(\mathrm{M})$ and $\mathrm{M}: \mathrm{SP}$ ratio did not differsignificantly between investigated sites (Table 1).

\subsection{EM colonization in relation to soil parameters}

The EMF colonization of the fine root tips at all test sites investigated ranged from $19 \%$ to $48 \%$. In general, statistical analysis demonstrated significantly higher portions of EM root tips at test sites II and IV. As a result, the highest levels of NM fine root tips were observed at test sites I, III and V (Fig. 1). The RDA analysis demonstrated that the colonization rates do not directly correlate with environmental properties (Fig. 2). The most colonized root tips of sites II and IV were at the opposite ends of the first ordination axis representing the environmental gradient. This was confirmed by the forward selection procedure and the Monte Carlo permutation test, neither of which identified factors significantly responsible for the level of EM colonization.

\subsection{Taxonomic diversity of EM morphotypes in relation to soil parameters}

Based on the morpho-anatomical properties we distinguished twenty EM morphotypes in total: seven morphotypes at plot II, four at plots I and IV, three at plot $\mathrm{V}$ and two at plot III (Supplementary material 1 Tab. A). Molecular analyses based on the ITS region and the NCBI/UNITE database resulted in the identification of nine different fungal strains. The most abundant EM fungal symbionts belonged to the phylum Basidiomycota: Tomentella sp., T. testaceogilva, and Thelephora alnii. Other isolated morphotypes were associated with fungi classified in the phylum Ascomycota: Helotiales,

Table 1 Results of the analysis of soil properties (mean \pm standard deviation) and Kruskal - Wallis test with the Dunn post hoc comparisons for the five positions (I-V)

\begin{tabular}{|c|c|c|c|c|c|c|}
\hline & \multicolumn{6}{|l|}{ Plots } \\
\hline & I & II & III & IV & $\mathrm{V}$ & $p$ \\
\hline $\mathrm{EC}_{\mathrm{e}}\left(\mathrm{dS} \cdot \mathrm{m}^{-1}\right)$ & 2.54 & 3.58 & 5.46 & 5.62 & 6.85 & - \\
\hline $\mathrm{EC}_{1: 5}\left(\mathrm{dS} \cdot \mathrm{m}^{-1}\right)$ & $403 \pm 6^{\mathrm{a}}$ & $486 \pm 26^{\mathrm{ab}}$ & $760 \pm 30^{b}$ & $466 \pm 12^{\mathrm{ab}}$ & $533 \pm 21^{\mathrm{ab}}$ & 0.01 \\
\hline $\mathrm{Cl}_{\mathrm{e}}\left(\mathrm{mg} \cdot \mathrm{dm}^{-1}\right)$ & $717 \pm 14^{\mathrm{a}}$ & $1000 \pm 25^{a b}$ & $1725 \pm 25^{a b}$ & $1867 \pm 14^{b}$ & $2225 \pm 50^{\mathrm{ab}}$ & 0.01 \\
\hline $\mathrm{pH}_{\mathrm{e}}$ & 7.8 & 7.5 & 6.7 & 4.8 & 7.5 & - \\
\hline $\mathrm{pH}_{1: 5}$ & $7.15 \pm 0.03^{b}$ & $7.05 \pm 0.01^{\mathrm{ab}}$ & $6.58 \pm 0.05^{\mathrm{ab}}$ & $5.66 \pm 0.05^{\mathrm{a}}$ & $6.73 \pm 0.03^{\mathrm{ab}}$ & 0.01 \\
\hline $\mathrm{OM}(\%)$ & $11.46 \pm 0.08^{b}$ & $8.06 \pm 0.02^{\mathrm{ab}}$ & $10.01 \pm 0.14^{\mathrm{ab}}$ & $4.80 \pm 0.04^{\mathrm{ab}}$ & $3.24 \pm 0.01^{\mathrm{a}}$ & 0.01 \\
\hline $\mathrm{C}(\%)$ & $4.96 \pm 0.10^{b}$ & $4.38 \pm 0.05^{\mathrm{ab}}$ & $3.91 \pm 0.09^{\mathrm{ab}}$ & $2.33 \pm 0.02^{\mathrm{ab}}$ & $1.79 \pm 0.02^{\mathrm{a}}$ & 0.01 \\
\hline $\mathrm{N}_{\mathrm{t}}(\%)$ & $0.386 \pm 0.006^{\mathrm{b}}$ & $0.352 \pm 0.002^{\mathrm{ab}}$ & $0.305 \pm 0.007^{\mathrm{ab}}$ & $0.195 \pm 0.002^{\mathrm{ab}}$ & $0.141 \pm 0.003^{\mathrm{a}}$ & 0.01 \\
\hline $\mathrm{P}\left(\mathrm{mg} \cdot \mathrm{kg}^{-1}\right)$ & $51.4 \pm 1.1^{\mathrm{b}}$ & $50.4 \pm 1.2^{\mathrm{ab}}$ & $36.7 \pm 0.7^{\mathrm{ab}}$ & $31.4 \pm 0.7^{\mathrm{a}}$ & $34.8 \pm 0.5^{\mathrm{ab}}$ & 0.01 \\
\hline $\mathrm{P}_{2} \mathrm{O}_{5} \mathrm{ca}\left(\mathrm{mg} \cdot \mathrm{kg}^{-1}\right)$ & $118.7 \pm 2.5^{b}$ & $116.4 \pm 2.8^{\mathrm{ab}}$ & $84.8 \pm 1.5^{\mathrm{ab}}$ & $72.4 \pm 1.6^{\mathrm{a}}$ & $80.4 \pm 1.3^{\mathrm{ab}}$ & 0.01 \\
\hline $\mathrm{M}(\%)$ & $64.9 \pm 13.0^{\mathrm{a}}$ & $69.2 \pm 4.7^{\mathrm{a}}$ & $57.4 \pm 10.1^{\mathrm{a}}$ & $36.4 \pm 6.1^{\mathrm{a}}$ & $35.3 \pm 6.8^{\mathrm{a}}$ & ns \\
\hline SP $(\%)$ & $68.3 \pm 2.2^{b}$ & $67.1 \pm 1.3^{\mathrm{ab}}$ & $65.1 \pm 1.2^{\mathrm{ab}}$ & $42.7 \pm 1.0^{\mathrm{ab}}$ & $38.6 \pm 1.4^{\mathrm{a}}$ & 0.01 \\
\hline M:SP & $0.95 \pm 0.19^{\mathrm{a}}$ & $1.03 \pm 0.04^{\mathrm{a}}$ & $0.88 \pm 0.15^{\mathrm{a}}$ & $0.85 \pm 0.17^{\mathrm{a}}$ & $0.91 \pm 0.15^{\mathrm{a}}$ & $\mathrm{ns}$ \\
\hline
\end{tabular}

Variants labelled with the same letters are not significantly different $(p \leq 0.05)$

Abbreviations: $E C_{e}$, electrical conductivity of the saturated extract; $E C_{1: 5}$, electrical conductivity in 1:5 soil to water extract; $C l_{e}$, chloride content in saturated extract; $p H_{e}$, reaction in saturated extract; $p H_{1: 5}$, reaction in 1:5 soil to water extract; $O M$, organic matter content; $C$, organic carbon; $N_{t}$, total nitrogen; $P$, phosphorus content; $\mathrm{P}_{2} \mathrm{O}_{5} \mathrm{ca}$, phosphorus soluble in citric acid; $n s$, not significant 


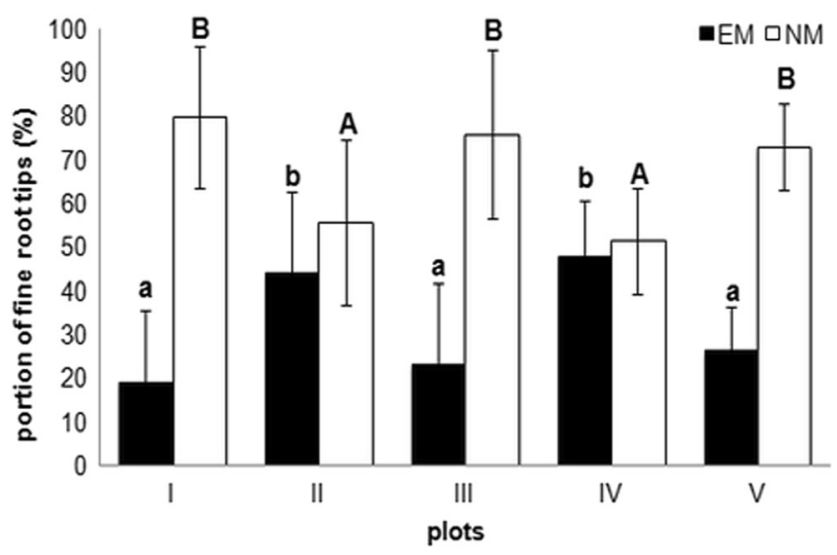

Fig. 1 Ectomycorrhizal (EM) and non-mycorrhizal (NM) fine root tips (\%, mean \pm Std dev.) of A. glutinosa at the five tested plots (I-V) $(\mathrm{p} \leq 0.05)$. Variants labelled with the same letters are not significantly different $(\mathrm{p} \leq 0.05)$ (Kruskal - Wallis and Dunn test as a post hoc comparison)

Meliniomyces sp., Neonectria sp., Oidiodendron sp., and Pezicula melanigena. Eight of the identified fungi were classified to the species level (Pezicula melanigena IV G; Tomentella testaceogilva V C, II C, I B, and IV A; Thelephora alnii V E, II H, and III B), four to the genus level (Meliniomyces sp., Neonectria sp., Oidiodendron sp., Tomentella sp.) and two to the order level (Helotiales I E and III H) (Supplementary material 1 Tab. A, Phot. A). In the case of the two EM morphotypes distinguished, we obtained high quality sequences in the form of contigs of both primers, although clear results

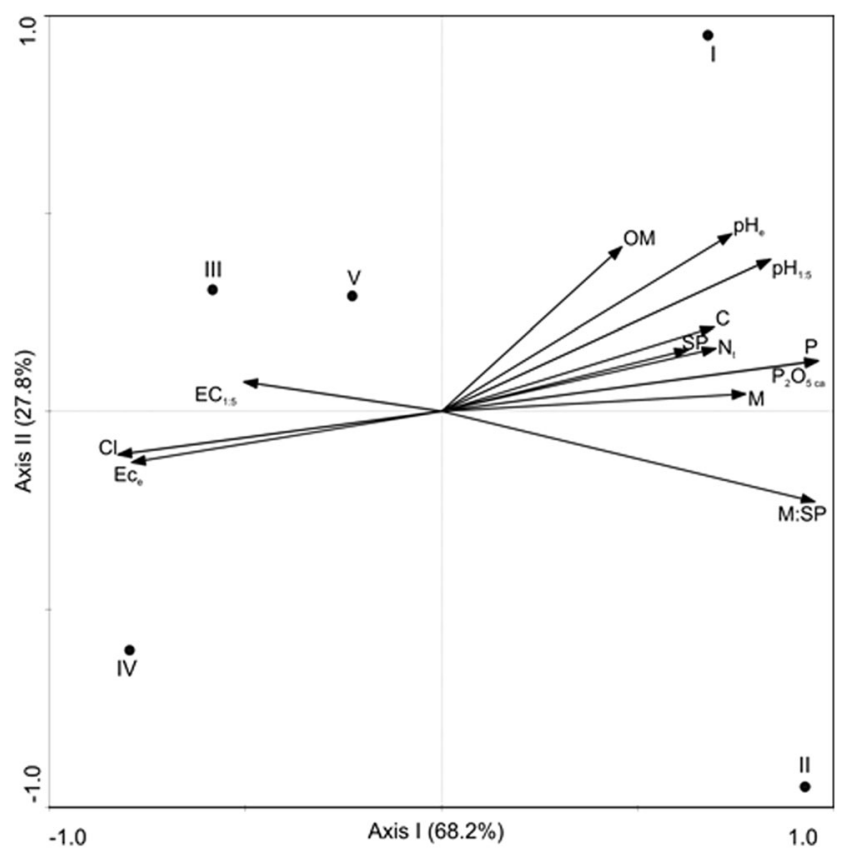

Fig. 2 Redundancy Analysis, diagram with axes 1 and 2 for the level of EM colonization of A. glutinosa in the five plots (I-V) and the soil properties in the rhizosphere. Abbreviations as in Table 1 could not be obtained while matching sequences at NCBI/UNITE. These are probably new ectomycorrhizal species of A. glutinosa: (1) ectomycorrhiza A. glutinosa $\mathrm{V}$ F, formed by a fungus belonging to the order Sordariales, and (2) ectomycorrhiza A. glutinosa I F, belonging to the order Helotiales. One isolated morphotype marked as I C was identified as a member of the family Thelephoraceae based on morpho-anatomical features. Problems with the molecular identification of the last three fungi marked as not identified (NI) may be associated with the high level of necrotic or old mycorrhizal tips and further problems with isolation of their DNA. Morpho-anatomical features of these ectomycorrhizal morphotypes are described in Supplementary material 1 Tab. A.

Phylogenetic analysis enabled the morphotypes identified to be distinguished into four groups with the following percentage contributions based on molecular and anatomical data: (1) order Thelephorales - 62\%, (2) class Leotiomycetes $26 \%$, (3) class Sordariomycetes $-8 \%$ and (4) other not identified (NI) fungi $-4 \%$ (Fig. 3). The percentage contribution of the fungal groups isolated from the five test plots is presented in Fig. 4. The dominant group of EMF included fungi belonging to the order Thelephorales and the family Thelephoraceae (Tomentella sp. and Thelephora sp.) (Fig. 4). They represented from $24 \%$ to $90 \%$ of all EM morphotypes in each plot. A lower level of colonization was revealed by fungi from class Leotiomycetes (12-48\% at plots I-IV) that included Helotiales and Oidiodendron sp. The group of Sordariomycetes was identified at plots II and V, with a $31 \%$ and $10 \%$ share, respectively. Fig. 3 shows that fungi belonging to the class of Sordariomycetes, Sordariales and Hypocreales - are phylogenetically distant. We performed several phylogenetic analyses using the sequences of identified morphotypes and random sequences from NCBI representing Neonectria sp. and Sordariales fungi that confirmed that these fungal taxa are located on branches of the phylogenetic tree far removed from each other.

Unlike the total colonization rate, the colonization of EM fungal groups was related to soil properties at the plots investigated (Fig. 5). The RDA analysis revealed that the salinity levels expressed as $\mathrm{EC}_{1: 5}$ and $\mathrm{EC}_{\mathrm{e}}$ correlated positively with the percentage distribution of fungi belonging to the order Thelephorales. According to the forward selection procedure and permutation test both parameters significantly explained $43 \%$ of the fungal variation in the sites investigated. The distribution of other the fungal groups (Leotiomycetes, Sordariomycetes and other NI fungi) correlated positively with the level of total phosphorus, which explained $20 \%$ of the variation and correlated negatively with salinity. Other physicochemical parameters were not significant according to the Monte Carlo permutation test. 


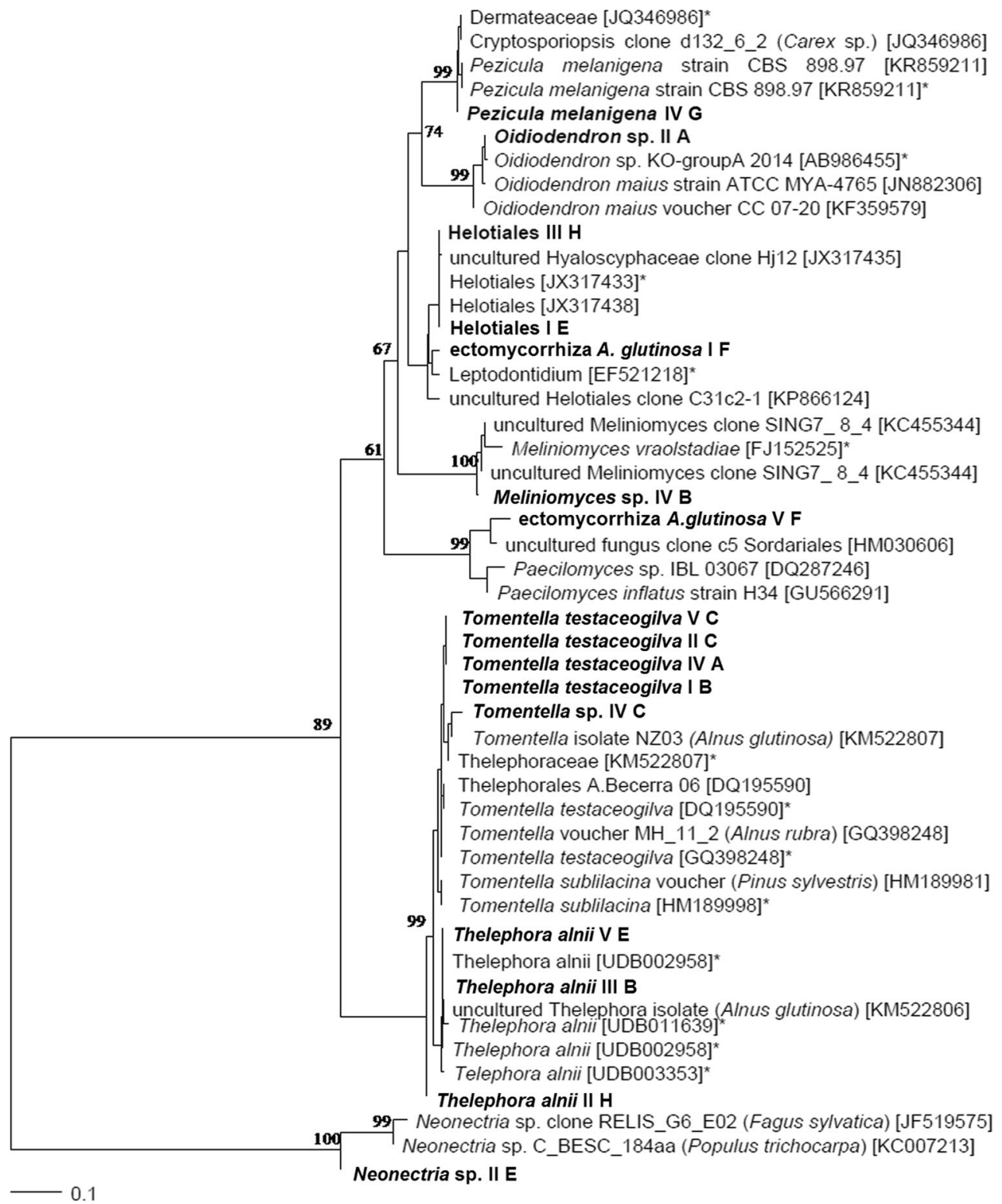

Leotiomycetes $26 \%$

Sordariomycetes (Sordariales) 2\%

Agaricomycetes (Thelephorales) 62\%

Sordariomycetes (Hypocreales) 6\%

Fig. 3 The phylogenetic tree of identified fungal morphotypes isolated from roots of A. glutinosa in a saline area

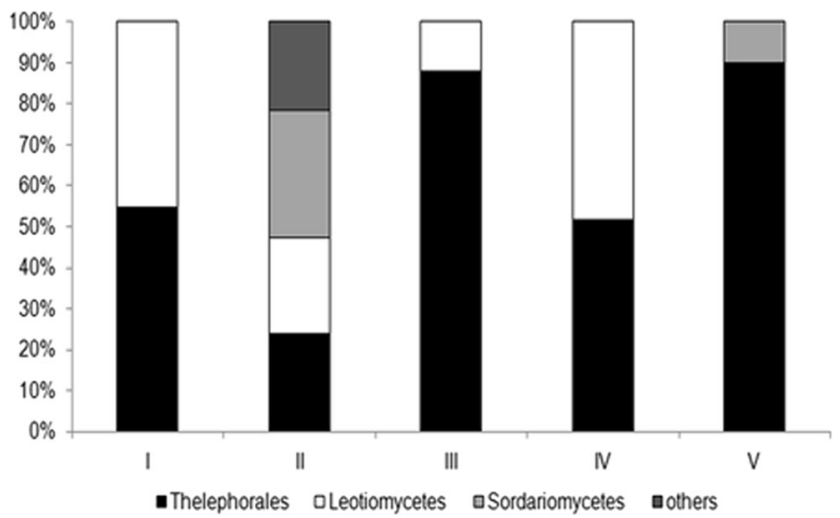

Fig. 4 The percentage contribution of fungal classes isolated from the five tested plots (I-V)
The highest species richness and $\mathrm{H}^{\prime}$ were observed for plot II (slightly saline), but they did not differ significantly from plot IV (moderately saline). The lowest diversity measurements were observed for plots III and V (moderately saline) and did not differ significantly from plot I (S) and, in the case of $\mathrm{H}^{\prime}$, from plots I and IV (Table 2). There was a significant negative correlation of calculated species richness and diversity index $\left(\mathrm{H}^{\prime}\right)$ with the level of salinity expressed as $\mathrm{EC}_{\mathrm{e} 1: 5}$. A significant negative correlation was observed between $\mathrm{S}$ and $\mathrm{EC}_{\mathrm{e} 1: 5}(\mathrm{r}=-0.5395$; $p=0.038$ ) (Fig. 6) and between the $\mathrm{H}^{\prime}$ index and $\mathrm{EC}_{\mathrm{e} 1: 5}$ ( $\mathrm{r}=-0.6814 ; p=0.050$ ) (Fig. 7). $\mathrm{S}$ and $\mathrm{H}^{\prime}$ significantly correlated with $\mathrm{EC}_{\mathrm{e}}$ or the total phosphorus level (data not shown). 


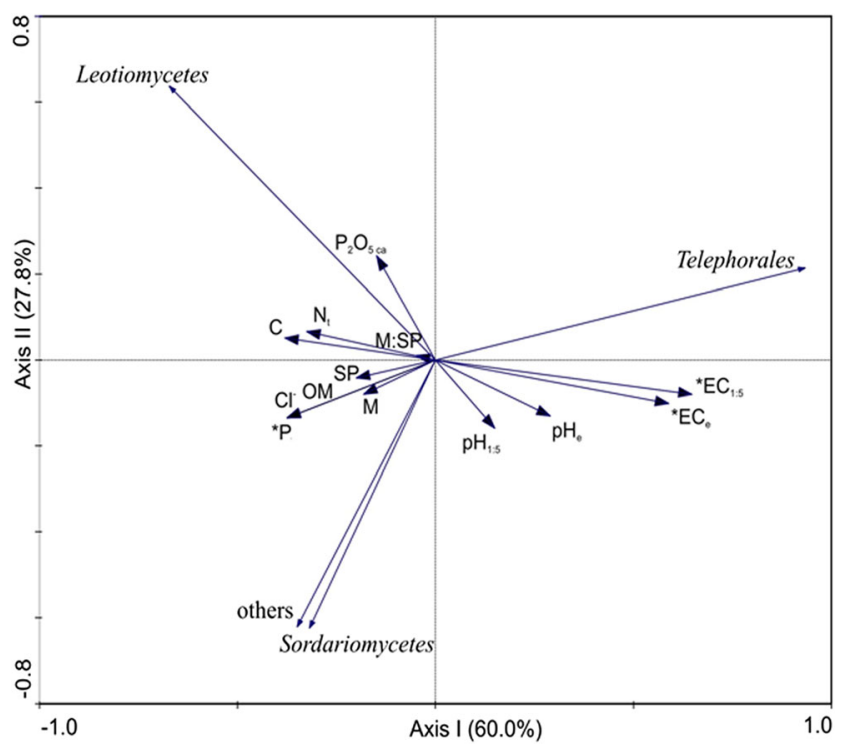

Fig. 5 Redundancy Analysis, diagram with axes 1 and 2 for percentage of fungal symbionts A. glutinosa was distinguished at the class level on the basis of molecular identification at the five plots $(\mathrm{I}-\mathrm{V})$ and the soil properties in the rhizosphere. Abbreviations as in Tab. $1 . * \mathrm{p} \leq 0.05$

\section{Discussion}

It is well known that EM colonization is sensitive to unfavourable soil conditions such as nutrient deficiencies or pollutants (McAfee and Fortin 1989; Hrynkiewicz and Baum 2012). The plots analysed in this study were classified as slightly saline (I and II) or moderately saline (III, IV and V) and had different physicochemical properties. The plots with the most extreme parameters were: plot $\mathrm{V}$, with the highest salinity and lowest values of $\mathrm{OM}, \mathrm{C}$, and $\mathrm{N}_{\mathrm{t}}$, plot I, with the lowest salinity and highest values of $\mathrm{OM}, \mathrm{C}, \mathrm{N}_{\mathrm{t}}$, and P content, and plot IV, with the lowest $\mathrm{pH}$ and $\mathrm{P}$ content. Piernik et al. (2015) also described such a large amount of local variation in the soil parameters of inland salt marshes. Salinity was the most important parameter analysed in this study. High salinity can adversely affect the germination of spores, the growth of fungal hyphae and the colonization capacity of fungi (Evelin et al. 2009; Hameed et al. 2014), and the final abundance of $\mathrm{EM}$ on tree roots. It is known that in natural forests, phosphorus $(\mathrm{P})$ is present in insoluble complexes and is generally unavailable to plants. Under these conditions, mycorrhizal fungi can increase the absorption ability of the plant (Jilkova

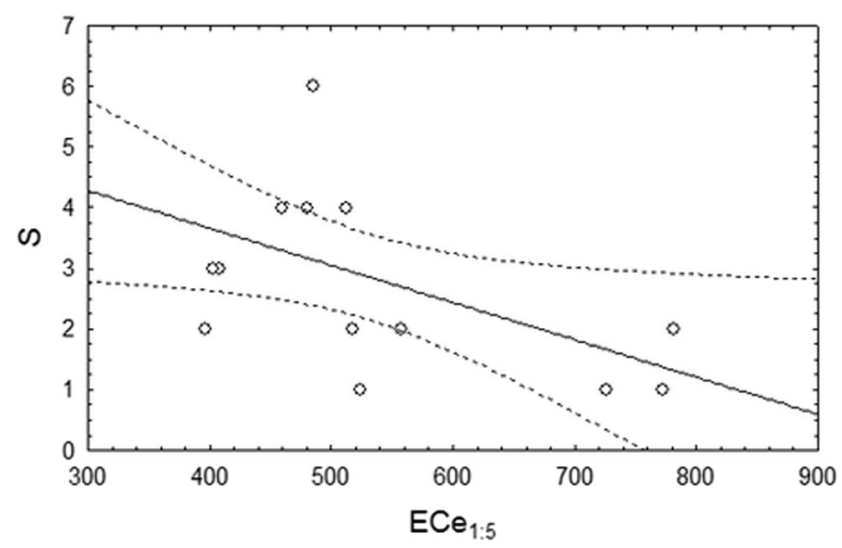

Fig. 6 Correlation between species richness (S) and the level of salinity $\left(\mathrm{EC}_{\mathrm{e} 1: 5}\right)(n=15 ; r=-0.5395 ; p=0.038)$

et al. 2015), which is why the host plants can promote the formation of mycorrhizal symbiosis. P ttsepp et al. (2004) observed a higher level of EM colonization on the root tips of Salix viminalis and $S$. dasyclados at lower P levels. Environmental conditions that may affect EM colonization also include soil pH (P ttsepp et al. 2004) since EMs typically form in acid soils (Cullings and Makhija 2001). In general, a lower $\mathrm{pH}$ increases the EM colonization rates (P ttsepp et al. 2004). However, contrary to our first hypothesis, we did not observe a direct effect of salinity on EM colonization. The lowest values were observed at the moderately saline plots $\mathrm{V}$ and III but also at the slightly saline plot I. There was generally a positive correlation between salinity gradients that could limit EM colonization rates. Alternatively, low $\mathrm{P}$ content and lower soil pH could stimulate EM colonization (Fig. 2). As a result of the simultaneous interaction of factors positively and negatively affecting EM colonization rates, the direct effect of the salinity level could not be observed. Moreover, fungi that have adapted well to saline soils can show a similar degree of colonization and lack a correlation with soil conditions, especially the level of salinity.

Our experiment confirmed a significant effect of soil salinity on EMF associated with A. glutinosa. We noted that the level of EM colonization of A. glutinosa (19\% and 48\%) at the saline plots investigated in this study was similar to the values observed at other unfavourable test sites. Similar results were obtained with Salix caprea, S. alba and Betula pendula growing in other saline areas of Poland (16-34\%) (Hrynkiewicz
Table 2 Measurements of diversity for the plots analysed (IV) (average \pm SD) and ANOVA with the Tukey post hoc comparisons for the five positions (I-V)

\begin{tabular}{lllllll}
\hline plot & I & II & III & IV & V & p \\
\hline $\mathrm{S}$ & $\begin{array}{c}2.667 \pm 0.578 \\
\text { ab }\end{array}$ & $\begin{array}{c}4.667 \pm 1.155 \\
\mathrm{c}\end{array}$ & $\begin{array}{c}1.333 \pm 0.578 \\
\mathrm{a}\end{array}$ & $\begin{array}{c}4.000 \pm 0.000 \\
\mathrm{bc}\end{array}$ & $1.667 \pm 0.557^{\mathrm{a}}$ & 0,00049 \\
$\mathrm{H}^{\prime}$ & $0.913 \pm 0.227$ & $\begin{array}{c}1.434 \pm 0.214 \\
\mathrm{cc}\end{array}$ & $\begin{array}{c}0.586 \pm 0.338 \\
\mathrm{a}\end{array}$ & $\begin{array}{c}1.044 \pm 0.084 \\
\mathrm{bc}\end{array}$ & $\begin{array}{c}0.522 \pm 0.095 \\
\mathrm{ab}\end{array}$ & 0,00026 \\
\hline
\end{tabular}

Variants labelled with the same letters are not significantly different $(p \leq 0.05)$

Abbreviations: $S$, species richness; $H^{\prime}$ - Shannon - Wiener diversity index 


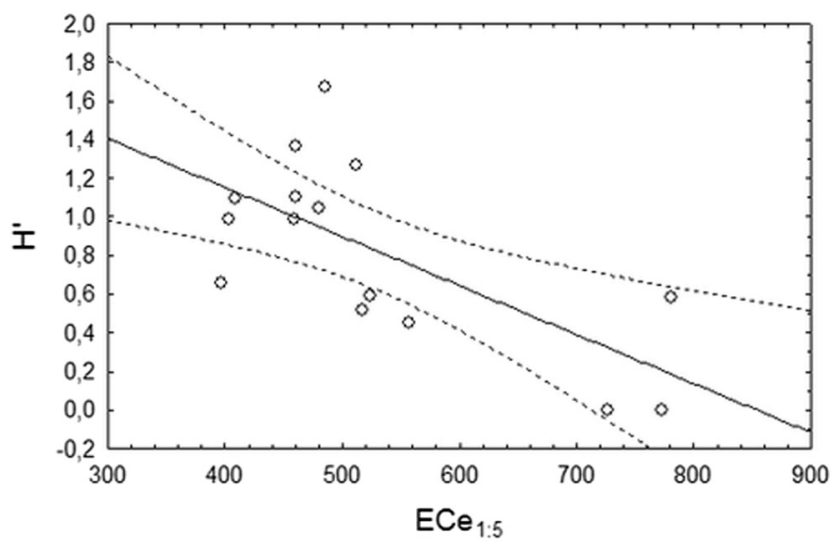

Fig. 7 Correlation between the level of diversity (described by $\mathrm{H}^{\prime}$ index) and salinity $\left(\mathrm{EC}_{\mathrm{e} 1: 5}\right)(\mathrm{n}=15 ; \mathrm{r}=-0.6814 ; p=0.050)$

et al. 2015), Salix linearistipularis growing in alkaline-saline soil (up to $\mathrm{pH} 9.2$ ) in northeastern China ( 42.3\%) (Ishida et al. 2009), and $S$. caprea present at test sites polluted with heavy metals in Germany (3-36\%) (Hrynkiewicz et al. 2008).

Previous research indicates that the number of different EM morphotypes observed on the roots of alders in natural environments that are not affected by any abiotic or biotic stress can vary between 11 and 16. Examples include 11 in red alder roots (Miller et al. 1991), 12 in A. acuminata roots (Becerra et al. 2005) and 16 in A. glutinosa roots (Pritsch et al. 1997). To the best of our knowledge, the available scientific literature lacks data on the level of the EM fungal colonization and diversity of EM fungal morphotypes associated with alders under salt stress. In our research we distinguished between two and seven different EM morphotypes per plot. This finding was similar to our previous studies on other tree species and under other types of abiotic stresses, such as 3-6 morphotypes on the roots of $S$. caprea in a mining area (Hrynkiewicz et al. 2008) and three morphotypes on Betula pendula subjected to salt stress (Hrynkiewicz et al. 2015).

The analysis of the taxonomic diversity of EMF on the roots of black alder growing under salt stress conditions revealed that the symbiotic fungi belonged to the order Thelephorales and the two classes Leotiomycetes and Sordariomycetes. Earlier studies indicated that A. glutinosa is associated with a lower number of EM fungi than other EM tree hosts (Pritsch et al. 1997; Tedersoo et al. 2009c; Põlme et al. 2013; Nouhra et al. 2014). The known EM symbionts identified on the roots of black alder include species that were not identified in our work, including Rusulla sp., Cortinarius sp., Lactarius sp., Alnicola sp. and Paxillus sp. (Pritsch et al. 1997), probably due to the higher sensitivity of these species to salinity. Interestingly, among the fungal groups identified, we did not observe any specific fungal lineages belonging to clades such as Alnicola or Alpova (Moreau et al. 2013; Roy et al. 2013), which is likely because abiotic soil parameters can affect Alnus EM communities (Becerra et al. 2005; Tedersoo et al. 2009a).
Salinity may affect fungal diversity and community composition by direct negative influence on their growth and physiological activity (Zhang et al. 2016). Based on this knowledge we hypothesized that salinity may preferentially stimulate fungal taxa with a greater level of adaptation to harsh soil conditions. In our studies the most common type of EMF belonged to the order Thelephorales, species of the tomentella-thelephora lineage (Basidiomycetes) (Tedersoo et al. 2009c). Statistical analyses revealed that these fungi colonized 50-90\% of the root tips in all of the plots investigated. A similar level of black alder seedling colonization by Thelephorales was observed by Nouhra et al. (2014) in a pot experiment (average $74.7 \%$ of EM). This also agrees with the analysis of $A$. acuminata that showed $65 \%$ of the morphotypes to be Tomentella sp. (Becerra et al. 2005). The large abundance of fungal symbionts classified in the order Thelephorales on alder roots was also observed by Tedersoo et al. (2009c), Pritsch et al. (2010) and Kennedy and Hill (2010). Some studies have indicated that members of the tomentella-thelephora lineage belong to the most globally species-rich fungi associated with Alnus (Põlme et al. 2013). Moreover, Tomentella sp. is a widespread EM fungus that sporulates in the organic soil horizon and is an important component of EM communities worldwide in arctic tundra, boreal forest, tropical and subtropical rain forest (Nouhra et al. 2014), and mature temperate forest stands (Taylor and Bruns 1999). However, they have been rarely studied and described in saline areas. Coccoloba uvifera L., known as a drought-hardy and nonhalophytic woody plant relatively tolerant to salinity and growing in slightly to moderately alkaline sandy soils, is well colonized by Scleroderma bermudense belonging to the Agaricomycetes class as Telephorales fungi (Séne et al. 2015) and improve the growth of seagrape plants under saline conditions (Bandou et al. 2006). Additionally, EM fungal communities of this tree is species-poor and implying ecological host specificity (Põlme et al. 2017). The most species-rich group inhabiting the roots of $C$. uvifera. is that of the tomentella-thelephora lineage (Põlme et al. 2017). This is similar to our results.

Interestingly, our analysis revealed a direct correlation between the occurrence of Thelephorales and level of salinity measured by electrical conductivity. Although the fungi from the genera Pisolithus, Laccaria and Suillus seem to be more tolerant to sodium salts than Thelephora in vitro (Dixon et al. 1993), this research does not reflect the multifactorial environmental conditions. The positive correlation between the abundance of Thelephorales and the level of salinity could reflect a high tolerance of species from this order to salt stress, possibly enabled by their morphological and physiological properties. All tomentelloid EMF in our experiment had the darkcoloured mantle typical of this group, from light brown to black, due to the incorporation of the natural dark pigment melanin in the cell wall, and the presence of thelephoric acid. 
Fungal melanins may act as a boundary between fungal cells and their environment and protect against physical, chemical and biological stresses (Vrålstad et al. 2002) including UV radiation, drying, and high concentrations of salts, heavy metals and radionuclides (Nonzom and Sumbali 2015). Melanised fungi exhibit improved resistance to high concentrations of salts because the presence of melanin in the cell wall reduces the flow of salt into the cells (Nonzom and Sumbali 2015). Moreover, melanin can have an indirect role protecting fungi against salt stress by binding excess salt and/ or synthesizing antioxidative enzymes (Bois et al. 2006; Kogej et al. 2007). The high number of melanised fungi in the samples analysed suggests an important role of these compounds in protecting fungal cells against salt stress. However, additional studies are needed to confirm our hypothesis. This is especially true since EMF can tolerate such difficult conditions using other defence mechanisms, such as the accumulation of osmolytes that have an important role in regulating the internal osmotic environment of hyphae, $\mathrm{Na}^{+}$efflux, or vacuolar sequestration of toxic ions such as $\mathrm{Na}^{+}$and $\mathrm{Cl}^{-}$(Chen et al. 2001).

Leotiomycetes were also particularly abundant on alder roots in our study (order Helotiales and family Myxotrichaceae). They represented $12-48 \%$ of the fungal taxa in the plots I-IV. Members of Helotiales comprise the largest group of undescribed root-associated fungi that thrive in various ecosystems and cover a broad range of niches (Wang et al. 2006). Most studies demonstrated that the Helotiales seem to be endophytes on a range of host plants (Ávila-Díaz et al. 2013). They were identified as endophytic fungi in the roots of orchids plants, such as Cephalanthera longifolia and C. damasonium (Herrera et al. 2010). Additionally, various groups of Helotiales were identified from EM root tips in northern hemisphere forests, as we have described (Vrålstad et al. 2002; Rosling et al. 2003; Tedersoo et al. 2009a). Toju et al. (2013) suggest that many recent studies have also reported "non-typical" plant-fungal associations that are not classified into the conventional categories of mycorrhizal symbiosis. This indicates different associations such as ericoid mycorrhizal fungi on ectomycorrhizal plants, ectomycorrhizal fungi on ericoid mycorrhizal plants, arbuscular mycorrhizal fungi on ectomycorrhizal plants, or ectomycorrhizal fungi on arbuscular mycorrhizal plants (Toju et al. 2013). Interestingly, members of Helotiales were identified in different regions affected by abiotic stresses including low temperature (Zhang et al. 2016), heavy-metal pollution (Vrålstad et al. 2002) and salinity (Hrynkiewicz et al. 2015). Our previous studies of ectomycorrhizal structure in a saline area revealed the Helotiales to be fungi associated with Betula spp. (Hrynkiewicz et al. 2015), a tree species known as a black alder that belongs to the family Betulaceae.

The Helotiales and Myxotrichaceae are paraphyletic groups of fungi (Wang et al. 2006). In our experiment, we identified one member of the family Myxotrichaceae Oidiodendron sp. Species of Oidiodendron are commonly isolated from ericoid fine roots, although some closely related species can colonize and even form ectomycorrhizal roots (Bergero et al. 2000; Vrålstad et al. 2002). Our results indicated that Oidiodendron sp. II A formed a dark brown mantle around the root that is typical for ectomycorrhizal fungi. In the experiments of Bergero et al. (2000), this species was found to be an endophyte on the roots of both flowering plants and trees.

Finally, we detected two fungi belonging to the Sordariomycetes. They included Neonectria sp. (order Hypocreales) in plot II and ectomycorrhizal V F (order Sordariales). Neonectria sp. formed a plectenchymatic dark brown mantle similar to the structure of Telephoraceae and represented $37.21 \%$ of the fungal symbionts in plot II. In the NCBI database Neonectria sp. is registered as an endophyte of two tree species: Fagus sylvatica and Populus trichocarpa. Additionally, Gao et al. (2011) identified Neonectria sp. as an endophyte of Cajanus cajan, a perennial legume from the family Fabaceae. Sordariales have also been identified from ectomycorrhizal root tips on other host trees such as those from the tropics in the family Dipterocarpaceae (Phosri et al. 2012) and Pinus montezumae (Garibay-Orijel et al. 2013). The sequences of morphotype V F revealed $89 \%$ similarity with Paecilomyces sp. that is recognized plant endophyte. Analysis of cucumbers growing under salt stress indicated that inoculation of the plants by endophyte $P$. formosus increased biomass of shoots by up to approximately $4.5 \%$ compared to a non-inoculated control at $60 \mathrm{mM} \mathrm{NaCl}$. In this case, the $P$. formosus association counteracted the adverse effects of salinity by accumulating proline and antioxidants and maintaining water potential of the plant (Khan et al. 2012).

The RDA results that analysed the distribution of fungal classes and soil parameters demonstrated that the total phosphorus content in the soil is a factor structuring fungal communities. Moreover, the concentration of phosphorus was directly correlated with the abundance of some fungal groups. The analysis determined that phosphorus can affect the distribution of different fungal taxa that belong to the Leotiomycetes or Soradiomycetes class. To the best of our knowledge, there is a lack of information indicating positive correlations between the occurrence of the fungal taxa described above and the total phosphorus content in the soil.

Differences of diversity were observed between the plots analysed, but they were not related to the salinity level in general. The diversity of EMF was always relatively low, as described previously for alders, and never exceeded 4.6 species per site. The distinct nature of Alnus EM assemblages is widely recognized but the mechanisms determining their lower richness and higher proportion of host-specific species are less clearly understood (Kennedy and Hill 2010). Huggins et al. (2014) demonstrated experimentally that Alnus EMF 
symbionts may be particularly adapted to high $\mathrm{N}$ and acidity conditions, suggesting that soil parameters, linked with Frankia activity on the root, might explain part of this specificity. In our study, we also detected that species richness and the $\mathrm{H}^{\prime}$ diversity index correlate negatively with the level of salinity expressed as $\mathrm{EC}_{\mathrm{e} 1: 5}$ but not with $\mathrm{EC}_{\mathrm{e}}$. Further experiments would help confirm the effect of $\mathrm{EC}_{\mathrm{e} 1: 5}$ on Alnus $\mathrm{EMF}$. The RDA results indicated that the total phosphorus content in the soil structured the EMF communities. Indeed, the concentration of phosphorus directly correlated with the abundance of species belonging to the Leotiomycetes or Soradiomycetes classes, but did not correlate with total species richness and the $\mathrm{H}^{\prime}$ diversity index. Phosphorus does not appear to be a main factor controlling EMF communities on alders according to the literature (Tedersoo et al. 2009c). This is also true for EMF communities in general (Tedersoo et al. 2012), probably because distinct phosphorus classes should be considered. Indeed, phosphorus can occur in the soil indifferent forms that are not all used by EMF fungi.

In conclusion, we must reject our first hypothesis that increasing salt concentrations would decrease the level of EM colonization in the site investigated, but we have confirmed our second assumption that salinity is an important factor affecting the EM taxonomic diversity of A. glutinosa. Increasing salinity was positively correlated with a greater proportion of EMF belonging to the order Thelephorales. Our results revealed that the distribution of Telephorales depends on the level of salinity. However, little is known about Thelephorales fungi and their mechanisms of adaptation to increased salinity is not yet known. Based on these results, the reaction of Alnus individuals should be studied, to determine if the fungi identified on their roots reduced the salt stress, and could increase the adaptation of alder to salty habitats.

Acknowledgements This investigation was conducted under the framework of COST (European Cooperation in Science and Technology) actions FA1103 and FA0901, and financially supported by two grants from the National Science Centre (Poland) (OPUS DEC-2012/ 07/ B/NZ9/01801 and PRELUDIUM DEC-2016/23/N/NZ8/00294). The authors wish to thank Dr. Miłosz Deptuła for his help in the field works.

Open Access This article is distributed under the terms of the Creative Commons Attribution 4.0 International License (http:// creativecommons.org/licenses/by/4.0/), which permits unrestricted use, distribution, and reproduction in any medium, provided you give appropriate credit to the original author(s) and the source, provide a link to the Creative Commons license, and indicate if changes were made.

\section{References}

Agerer R (1991) Characterization of ectomycorrhiza. In: Norris JR, Read DJ, Varma AK (eds) Techniques for the study of mycorrhiza. Academic, London, pp 50-51
Agerer R (ed) (1987-2002) Colour Atlas of Ectomycorrhizae, first to twelfth ed. Schwöbisch Gm nd, Einhorn

Aggarwal A, Kadian N, Tanwar A, Gupta KK (2012) Arbuscular mycorrhizal symbiosis and alleviation of salinity stress. J Appl Natural Sci 4(1):144-155

Ávila-Díaz I, Garibay-Orijel R, Magaña-Lemus RE, Oyama K (2013) Molecular evidence reveals fungi associated within the epiphytic orchid Laelia speciosa (HBK) Schltr. Bot Sci 91(4):523-529

Bandou E, Lebailly F, Muller F, Dulormne M, Toribio A, Chabrol J, Courtecuisse R, Plenchette C, Prin Y, Duponnois R, Thiao M, Sylla S, Dreyfus B, Bâ AM (2006) The ectomycorrhizal fungus Scleroderma bermudense alleviates salt stress in seagrape (Coccoloba uvifera L.) seedlings. Mycorrhiza 16:559-565. https:// doi.org/10.1007/s00572-006-0073-6

Becerra AB, Ritschb KP, Rrigoc NA, Almac MP, Artolonid NB (2005) Ectomycorrhizal colonization of Alnus acuminata Kunth in northwestern Argentina in relation to season and soil parameters. Ann For Sci 62:325-332. https://doi.org/10.1051/forest:2005027

Bednarek R (2005) Laboratoryjne badania gleb. In: Bednarek R, Dziadowiec H, Pokojska U, Prusinkiewicz Z Badania ekologiczno-gleboznawcze. Wydawnictwo Naukowe PWN, Warszawa, pp 100-111

Bergero R, Perotto S, Girlanda M, Vidano G, Luppi AM (2000) Ericoid mycorrhizal fungi are common root associates of a mediterranean ectomycorrhizal plant (Quercus ilex). Mol Ecol 9(10):1639-1649. https://doi.org/10.1046/j.1365-294X.2000.01059.x

Bois G, Bertrand A, Piché Y, Fung M, Khasa DP (2006) Growth, compatible solute and salt accumulation of five mycorrhizal fungal species grown over a range of $\mathrm{NaCl}$ concentrations. Mycorrhiza 16:99109. https://doi.org/10.1007/s00572-005-0020-y

Cabot C, Sibole JV, Barcelo J, Poschenrieder C (2014) Lessons from crop plants struggling with salinity. Plant Sci 226:2-13. https://doi.org/ 10.1016/j.plantsci.2014.04.013

Chandrasekaran M, Boughattas S, Hu S, Oh S, Sa T (2014) A metaanalysis of arbuscular mycorrhizal effects on plants grown under salt stress. Mycorrhiza 3:611-625. https://doi.org/10.1007/s00572014-0582-7

Chen DM, Ellul S, Herdman K, Cairney JWG (2001) Influence of salinity on biomass production by Australian Pisolithus spp. isolates. Mycorrhiza 11(5):231-236. https://doi.org/10.1007/ s005720100126

Chen S, Hawighorst P, Sun J, Polle A (2014) Salt tolerance in Populus: Significance of stress signaling networks, mycorrhization, and soil amendments for cellular and whole-plant nutrition. Environ Exp Bot 107:113-124. https://doi.org/10.1016/j.envexpbot.2014.06.001

Claessens H, Oosterbaan A, Savill P, Rondeux J (2010) A review of the characteristics of black alder (Alnus glutinosa (L.) Gaertn.) and their implications for silvicultural practices. Forestry 83(2):163-175. https://doi.org/10.1093/forestry/cpp038

Cullings KEN, Makhija S (2001) Ectomycorrhizal Fungal associates of Pinus contorta in soils associated with a hot spring in Norris Geyser Basin, Yellowstone National Park, Wyoming. Appl Environ Microb 67(12):5538-5543. https://doi.org/10.1128/AEM.67.12.5538

Diagne N, Arumugam K, Ngom M, Nambiar-Veetil M, Franche C, Narayanan KK, Laplaze L (2013) Use of Frankia and actinorhizal plants for degraded lands reclamation, Review Article. Hindawi Publishing Corporation BioMed Res Int. https://doi.org/10.1155/ 2013/948258

Dixon RK, Rao MV, Garg VK (1993) Salt stress affects in vitro growth and in situ symbioses of ectomycorrhizal fungi. Mycorrhiza 3:6368. https://doi.org/10.1007/BF00210694

Ellenberg H, Weber HE, Düll R, Wirth V, Werner W, Paulissen D (2001) Zeiger-werte von Pflanzen in Mitteleuropa, third ed. Scr Geobot 18: $1-248$ 
Evelin H, Kapoor R, Giri B (2009) Arbuscular mycorrhizal fungi in alleviation of salt stress: a review. Ann Bot-London 104(7):12631280. https://doi.org/10.1093/aob/mcp251

Felsenstein J (1985) Confidence limits on phylogenies: an approach using the bootstrap. Evolution 39:783-791. https://doi.org/10.2307/ 2408678

Gao Y, Zhao JT, Zu YG, Fu YJ, Wang W, Luo M, Efferth T (2011) Characterization of five fungal endophytes producing cajaninstilbene acid isolated from Pigeon Pea [Cajanus cajan (L.) Mill sp.] PLoS One 6(11):1-9. https://doi.org/10.1371/journal.pone. 0027589

Garibay-Orijel R, Morales-Marañon E, Domínguez-Gutiérrez M, FloresGarcía A (2013) Morphologic and genetic characterization of ectomycorrhizae formed by Pinus montezumae and spore bank fungi in the Transmexican Volcanic Belt. Rev Mex Biodiv 84(1):153169. https://doi.org/10.7550/rmb.29839

Hameed A, Dilfuza E, Abd-Allah EF, Hashem A, Kumar A, Ahmad P (2014) Salinity stress and arbuscular mycorrhizal symbiosis in plants In: Miransari M (ed) Use of microbes for the alleviation of soil stresses, vol 1. Springer, New York, pp 139-159

Helm DJ, Allen EB, Trappe JM (1996) Mycorrhizal chronosequence near Exit Glacier. Alaska, Can J Bot 74:1496-1506

Herrera P, Suárez JP, Kottke I (2010) Orchids keep the ascomycetes outside: a highly diverse group of ascomycetes colonizing the velamen of epiphytic orchids from a tropical mountain rainforest in Southern Ecuador. Mycology 1:262-268

Hrynkiewicz K, Baum C (2012) The potential of rhizosphere microorganisms to promote the plant growth in disturbed soils. In: Malik A, Grohmann E (red) Environmental Protection Strategies for Sustainable Development. Springer Science +805 Business Media B.V., Netherlands, pp 35-64

Hrynkiewicz K, Baum C, Leinweber P (2009) Mycorrhizal community structure, microbial biomass $\mathrm{P}$ and phosphatase activities under Salix polaris as influenced by nutrient availability. Eur J Soil Biol 45:168-175. https://doi.org/10.1016/j.ejsobi.2008.09.008

Hrynkiewicz K, Haug I, Baum C (2008) Ectomycorrhizal community structure under willows at former ore mining sites. Eur J Soil Biol 44(1):37-44. https://doi.org/10.1016/j.ejsobi.2007.10.004

Hrynkiewicz K, Szymańska S, Piernik A, Thiem D (2015) Ectomycorrhizal community structure of Salix and Betula spp. at a saline site in central Poland in relation to the seasons and soil parameters. Water Air Soil Poll 226(4):99. https://doi.org/10.1007/ s11270-015-2308-7

Huggins JA, Talbot J, Gardes M, Kennedy PG (2014) Unlocking environmental keys to host specificity: differential tolerance of acidity and nitrate by Alnus-associated ectomycorrhizal fungi. Fungal Ecol 12:52-61. https://doi.org/10.1016/j.funeco.2014.04.003

Ishida TA, Nara K, Ma S, Takano T, Liu S (2009) Ectomycorrhizal fungal community in alkaline-saline soil in northeastern China. Mycorrhiza 19(5):329-335. https://doi.org/10.1007/s00572-008-0219-9

Jackson ML (1958) Soil chemical analysis. Constable Ltd, London

Jilkovó V, Frouz J, Mudrók O, Vohnik M (2015) Effects of nutrient-rich substrate and ectomycorrhizal symbiosis on spruce seedling biomass in abandoned nests of the wood ant (Formica polyctena): a laboratory experiment. Geoderma 259-260:56-61. doi:https://doi.org/10. 1016/j.geoderma.2015.05.007

Kennedy PG, Hill LT (2010) A molecular and phylogenetic analysis of the structure and specificity of Alnus rubra ectomycorrhizal assemblages. Fungal Ecol 3(3):195-204. Elsevier Ltd: 195-204. doi: https://doi.org/10.1016/j.funeco.2009.08.005

Kennedy P, Nguyen N, Cohen H, Peay K (2014) Missing checkerboards? An absence of competitive signal in Alnus-associated ectomycorrhizal fungal communities. Peer J 16(2):e686. https:// doi.org/10.7717/peerj.686
Kernaghan G, Hambling B, Fung M, Khasa D (2002) In vitro selection of boreal ectomycorrhizal fungi for use in reclamation of salinealkaline habitats. Restor Ecol 1(10):43-51

Khan A, Hamayun M, Kang S, Kim Y, Jung H, Lee J, Lee I (2012) Endophytic fungal association via gibberellins and indole acetic acid can improve plant growth under abiotic stress: an example of Paecilomyces formosus LHL10. BMC Microbiol 12(1):3. https:// doi.org/10.1186/1471-2180-12-3

Kimura M (1980) A simple method for estimating evolutionary rates of base substitutions through comparative studies of nucleotide sequences. J Mol Evol 16:111-120

Kogej T, Stein M, Volkmann M, Gorbushina AA, Galinski EA, GundeCimerman N (2007) Osmotic adaptation of the halophilic fungus Hortaea werneckii: role of osmolytes and melanization. Microbiology 153(12):4261-4273. https://doi.org/10.1099/mic.0. 2007/010751-0

Lefrancois E, Quoreshi A, Khasad D, Funge M, Whyte LG, Roy S, Greera CW (2010) Field performance of alder - Frankia symbionts for the reclamation of oil sands sites. Appl Soil Ecol 46:183-191. https://doi.org/10.1016/j.apsoil.2010.08.010

McAfee BJ, Fortin JA (1989) Ectomycorrhizal colonization on black spruce and jack pine seedlings outplanted in reforestation sites. Plant Soil 116(1):9-17. https://doi.org/10.1007/BF02327251

Miller SL, Koo CD, Molina R (1991) Characterization of red alder ectomycorrhizae: a preface to monitoring belowground ecological responses. Can J Botany 69(3):516-531. https://doi.org/10.1139/ b91-071

Molina R, Massicotte H, Trappe JM (1992) Specificity phenomena in mycorrhizal symbioses: community-ecological consequences and practical implications. In: Allen MF (ed) Mycorrhizal symbiosis, an integrative plant-fungal process. Chapman and Hall, New York, pp 357-423

Moreau PA, Rochet J, Welti S, Peintner U, Manzi S, Courtecuisse R, Gardes M (2013) Agarics of alders - Three new species of Alnicola (Agaricales, Hymenogastraceae) with a key to species associated with Alnus alnobetula in Europe. Cryptogemie Mycol 34(2):149-173. https://doi.org/10.7872/crym.v34.iss2.2013.149

Nonzom S, Sumbali G (2015) Fate of mitosporic soil fungi in cold deserts: A review. AIJRFANS 9(1):1-9

Nouhra E, Pastor N, Becerra A, Areitio ES, Geml J (2014) Greenhouse seedlings of Alnus showed low host intrageneric specificity and a strong preference for some Tomentella ectomycorrhizal associates. Microb Ecol 69:813-825. https://doi.org/10.1007/s00248-014$0522-2$

Obidziński A (2004) Black alder (Alnus glutinosa Gaertn.) as a pioneer species in regeneration of fresh oak-linden-hornbeam forest (TilioCarpinetum Typicum Traczyk 1962) in Białowieża Forest (East Poland). Pol J Ecol 52(4):533-551

Parádi I, Baar J (2006) Mycorrhizal fungal diversity in willow forests of different age along the river Waal, The Netherlands. Forest Ecol Manag 237:366-372. https://doi.org/10.1016/j.foreco.2006.09.059

Phosri C, Põlme S, Taylor AFS, Kõljalg U, Suwannasai N, Tedersoo L (2012) Diversity and community composition of ectomycorrhizal fungi in a dry deciduous dipterocarp forest in Thailand. Biodivers Conserv 21(9):2287-2298. https://doi.org/10.1007/s10531-0120250-1

Piernik A, Hulisz P, Rokicka A (2015) Micropattern of halophytic vegetation on technogenic soils affected by the soda industry. Soil Sci Plant Nutr 61:98-112. https://doi.org/10.1080/00380768.2015. 1028874

Pritsch K, Becerra A, Põlme S, Tedersoo L, Schloter M, Agerer R (2010) Description and identification of Alnus acuminata ectomycorrhizae from argentinean alder stands. Mycologia 102(6):1263-1273. https://doi.org/10.3852/09-311

Pritsch K, Boyle H, Munch JC, Buscot F (1997) Characterization and identification of black alder ectomycorrhizas by PCR/RFLP 
analyses of the rDNA internal transcribed spacer (ITS). New Phytol 137(2):357-369. https://doi.org/10.1046/j.1469-8137.1997.00806.x

Põlme S, Bahram M, Yamanaka T, Nara K, Dai YC, Grebenc T, Kraigher $\mathrm{H}$ et al (2013) Biogeography of ectomycorrhizal fungi associated with alders (Alnus spp.) in relation to biotic and abiotic variables at the global scale. New Phytol 198(4):1239-1249. https://doi.org/10. 1111 /nph. 12170

Põlme S, Bahram M, Kõljalg U, Tedersoo L (2017) Biogeography and specificity of ectomycorrhizal fungi of Coccoloba uvifera. In: Tedersoo L (ed) Biogeography of Mycorrhizal Symbiosis. Springer, Berlin, pp 345-359

P ttsepp , Rosling A, Taylor AFS (2004) Ectomycorrhizal fungal communities associated with Salix viminalis L. and S. dasyclados Wimm. clones in a short-rotation forestry plantation. Forest Ecol Manag 196(2-3):413-424. https://doi.org/10.1016/j.foreco.2004. 04.003

Richards LA (ed) (1954) Diagnosis and improvement of saline and alkali soils. USDA, Washington

Rosling A, Landeweert R, Lindahl BD, Larsson KH, Kuyper TW, Taylor AFS, Finlay RD (2003) Vertical distribution of ectomycorrhizal fungal taxa in a podzol soil profile. New Phytol 159(3):775-783. https://doi.org/10.1046/j.1469-8137.2003.00829.x

Roy M, Rochet J, Manzi S, Jargeat P, Gryta H, Moreau P, Gardes M (2013) What determines Alnus-associated ectomycorrhizal community diversity and specificity? A comparison of host and habitat effects at a regional scale. New Phytol 198:1228-1238. https://doi. org/10.1111/nph.12212

Roy S, Khasa DP, Greer CW (2007) Combining alders, frankiae, and mycorrhizae for soil remediation and revegetation. Can J Bot 85: 237-251. https://doi.org/10.1139/B07-017

Sakalli A (2013) A simple model for predicting the global distribution of the $\mathrm{N}_{2}$ fixing host genus Alnus Mill.: impact of climate change on the global distribution in 2100. Biogeosci Discuss 10(8):13049 13095. https://doi.org/10.5194/bgd-10-13049-2013

Sati SC, Sati N, Sati OP (2011) Bioactive constituents and medicinal importance of genus Alnus. Pharmacogn Rev 5(10):174-183. https://doi.org/10.4103/0973-7847.91115

Selosse M-A, Baudoin E, Vandenkoornhuyse P (2004) Symbiotic microorganisms, a key for ecological success and protection of plants. C R Biol 327:639-648. https://doi.org/10.1016/j.crvi.2003.12.008

Shannon CE (1948) A mathematical theory of communication. Bell Syst Tech J 27:623-656

StatSoft (1995) - STATISTICA for Windows - Tulsa, StatSoft, Inc

Séne S, Avril R, Chaintreuil C, Geoffroy A, Ndiaye C, Diédhiou AG, Sadio O, Courtecuisse R, Sylla SN, Selosse M-A, Bâ A (2015) Ectomycorrhizal fungal communities of Coccoloba uvifera (L.) L. mature trees and seedlings in the neotropical coastal forests of Guadeloupe (Lesser Antilles). Mycorrhiza 25:547-559. https://doi. org/10.1007/s00572-015-0633-8

Swofford DL (2002) PAUP*: Phylogenetic Analysis Using Parsimony (*and other methods) Version 4b 10. Sinauer Associates, Sunderland

Szulczewski JW (1954) Solnisko słonawskie dawniej a dziś. Ochrona Przyrody 22:195-200

Taylor DL, Bruns TD (1999) Community structure of ectomycorrhizal fungi in a Pinus muricata forest: minimal overlap between the mature forest and resistant propagule communities. Mol Ecol 8(11):1837-1850. https://doi.org/10.1046/j.1365-294X.1999. 00773.x

Tedersoo L, Bahram M, Toots M, Diédhiou AG, Henkel TW, Kjøller R, Morris MH, Nara K, Nouhra E, Peay KG, Põlme S, Ryberg M, Smith ME, Kõljalg U (2012) Towards global patterns in the diversity and community structure of ectomycorrhizal fungi. Mol Ecol 21(17):4160-4170. https://doi.org/10.1111/j.1365-294X.2012. 05602.x

Tedersoo L, Gates G, Dunk CW, Lebel T, May TW, Köljalg U, Jairus T (2009a) Establishment of ectomycorrhizal fungal community on isolated Nothofagus cunninghamii seedlings regenerating on dead wood in Australian wet temperate forests: does fruit-body type matter? Mycorrhiza 19(6):403-416. https://doi.org/10.1007/s00572009-0244-3

Tedersoo L, Pồrtel K, Jairus T, Gates G, Pỡldmaa K, Tamm H (2009b) Ascomycetes associated with ectomycorrhizas: molecular diversity and ecology with particular reference to the Helotiales. Environ Microbiol 11(12):3166-3178. https://doi.org/10.1111/j.1462-2920. 2009.02020.x

Tedersoo L, Suvi T, Jairus T, Ostonen I, Pölme S (2009c) Revisiting ectomycorrhizal fungi of the genus Alnus: differential host specificity, diversity and determinants of the fungal community. New Phytol 182(3):727-735. https://doi.org/10.1111/j.1469-8137.2009.02792.x

ter Braak CJF, Šmilauer P (2002) CANOCO Reference manual and CanoDraw for Windows User's guide: Software for Canonical Community Ordination (version 4.5), Microcomputer Power, Ithaca, New York

Thompson JD, Gibson TJ, Plewniak F, Jeanmougin F, Higgins DG (1997) The CLUSTAL-windows interface: flexible strategies for multiple sequence alignment aided by quality analysis tools. Nucl Acid Res 25:4876-4882

Toju H, Sato H, Yamamoto S, Kadowaki K, Tanabe AS, Yazawa S, Nishimura O, Agata K (2013) How are plant and fungal communities linked to each other in belowground ecosystems? A massively parallel pyrosequencing analysis of the association specificity of root-associated fungi and their host plants. Ecol Evol 3(9):31123124. https://doi.org/10.1002/ece3.706

van Reeuwijk LP (2002) Procedures for soil analysis. ISRIC, Wageningen pp: $21,4-1-4-2,6-1-6-2,13-1,13-3,13-4-13-5$, 14-1-14-5

Vrålstad T, Schumacher T, Taylor AFS (2002) Mycorrhizal synthesis between fungal strains of the Hymenoscyphus ericae aggregate and potential ectomycorrhizal and ericoid hosts. New Phytol 153(1):143-152. https://doi.org/10.1046/j.0028-646X.2001.00290.

Wang Z, Johnston PR, Takamatsu S, Spatafora JW, Hibbett DS (2006) Toward a phylogenetic classification of the Leotiomycetes based on rDNA data. Mycologia 98(6):1065-1075. https://doi.org/10.3852/ mycologia.98.6.1065

Wilkoń-Michalska J (1963) Halofity Kujaw. Państwowe Wydawnictwo Naukowe, Torun

Zhang T, Wang NF, Zhang YQ, Liu HY, Yu LY (2016) Diversity and distribution of fungal communities in the marine sediments of Kongsfjorden, Svalbard (High Arctic). Microb Ecol 71(3):543554. https://doi.org/10.1007/s00248-015-0689-1 